\title{
Technical Issues Map for the NHI System Interface and Support Systems Area: $1^{\text {st }}$ Quarter FY 07
}

S.R. Sherman

December 2006

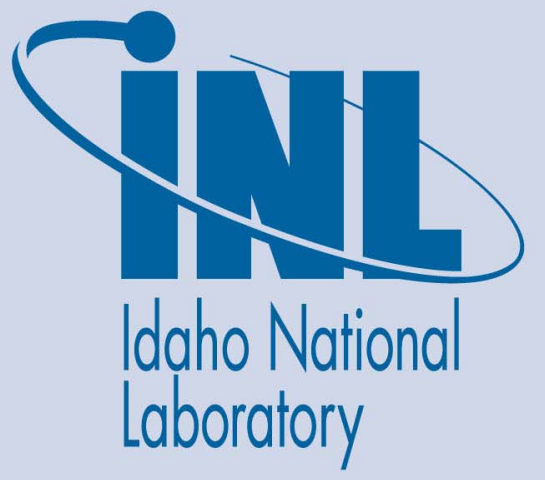

The INL is a U.S. Department of Energy National Laboratory operated by Battelle Energy Alliance 
INL/EXT-06-12045

\section{Technical Issues Map for the NHI System Interface and Support Systems Area: $1^{\text {st }}$ Quarter FY 07}

S.R. Sherman

December 2006

Idaho National Laboratory

Idaho Falls, Idaho 83415

Prepared for the

U.S. Department of Energy

Office of Nuclear Energy

Under DOE Idaho Operations Office

Contract DE-AC07-05ID14517 


\section{ABSTRACT}

This document provides a mapping of technical issues associated with development of the Next Generation Nuclear Plant (NGNP) intermediate heat transport loop and nuclear hydrogen plant support systems to the work that has been accomplished or is currently underway. The technical issues are ranked according to priority and by assumed resolution dates. Due to funding limitations, not all high-priority technical issues are under study at the present time, and more resources will need to be dedicated to tackling such issues in the future. This technical issues map is useful for understanding the relative importance of various technical challenges and will be used as a planning tool for future work package planning. 


\section{CONTENTS}

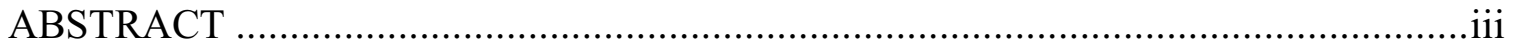

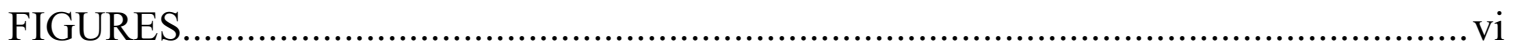

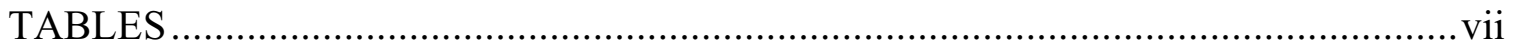

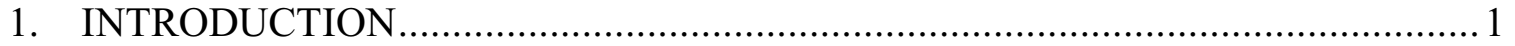

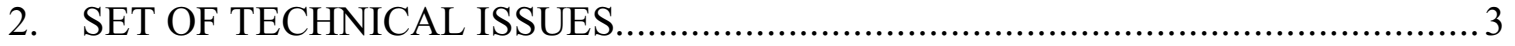

3. SET OF REPORTS AND PROJECTS ............................................................ 9

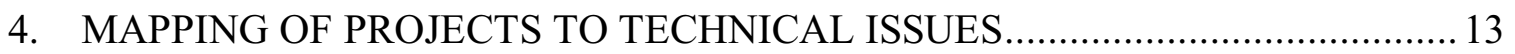

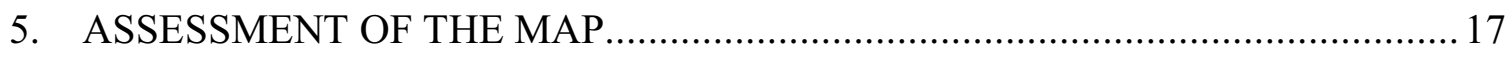

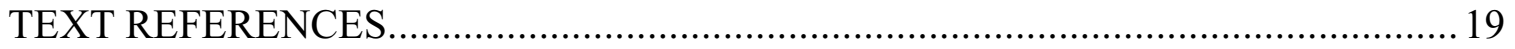

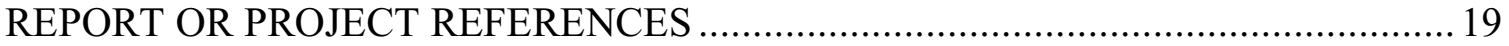

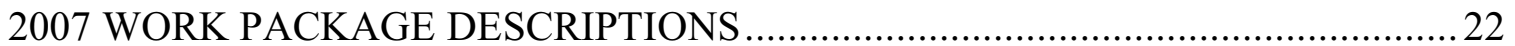




\section{FIGURES}

Figure 1. DOE Nuclear Hydrogen Initiative Project Schedule (Fall 2006) ....................2 


\section{TABLES}

Table 1. Set of Technical Issues .............................................................................. 3

Table 2. Sequential Ordering of Technical Issues and Goals ...................................... 6

Table 3. Set of System Interface and Supporting Systems Projects/Reports .................. 9

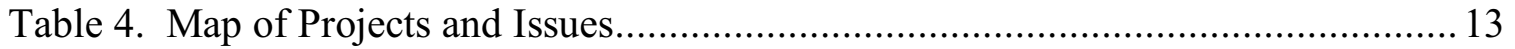




\section{INTRODUCTION}

This document provides a mapping of technical issues associated with development of the Next Generation Nuclear Plant (NGNP) intermediate heat transport loop and nuclear hydrogen plant support systems to the work that has been accomplished or is currently underway. The technical issues are ranked according to priority and by assumed resolution dates. Due to funding limitations, not all high-priority technical issues are under study at the present time, and more resources will need to be dedicated to resolving such issues in the future. This technical issues map is useful for understanding the relative importance of various technical challenges and will be used as a planning tool for future work package planning.

The NGNP Project also has responsibility for the development of parts of the intermediate heat transport loop including one or more Intermediate Heat Exchangers (IHX). Work has just begun on IHX development and energy conversion under the NGNP Project and has so far been confined to funding industry trade studies. The results of the industry trade studies will be available towards the end of FY07. No advanced information is available from these trade studies, and so the Technical Issues Map is written from the viewpoint of the DOE NHI. Once the results of the industry trade studies become available, it is expected that the list of technical issues and ranking of relative priorities will change significantly, and this Technical Issues Map will be altered accordingly. In recognition of the shared research and development responsibility for the intermediate heat transport loop and the technical implications of choices made by both projects, the Technical Issues Map will be modified from previous versions to include technical issues associated with the IHX.

The Map is presented as a series of tables. One table lists the set of technical issues or technological targets along with their relative importance. Another table lists the set of reports or projects that have been completed or are currently underway. A subsequent table shows the linkage between the set of technical issues and the set of completed or ongoing work. The importance of any one technical issue is determined by when the issue must be resolved in order to support the larger DOE NHI schedule. The latest DOE NHI project schedule is shown in Figure 1. Significant dates on the DOE NHI project schedules are: Intermediate heat transport loop fluid down-select, 2009; Begin pilot-scale plant construction, 2011; Begin engineering-scale hydrogen plant construction, 2015. All technical issues are arranged in priority to support either pilot-scale or engineering-scale deployment of nuclear hydrogen production technologies.

Following the Map is an assessment of how well the DOE NHI is performing in resolving the technical issues, and recommendations are given for any changes in research directions (if needed) and for additional projects.

Development of the Map is an attempt to systematically understand and catalog the multitude of technical issues that must be resolved in order to connect a high-temperature nuclear plant to a nuclear-heat-driven hydrogen production plant. It is hoped that this Map will prove useful to the greater NGNP-related development programs for future planning, and that it will be illustrative in sorting between issues that are feasibility-related (Go/No-Go) and issues that are more related to plant economics (capital cost improvements, efficiency improvements, etc.). Certainly the feasibility-related issues must be tackled first, but those related to plant economics must ultimately be resolved in order to build a successful and economically competitive NGNP. 


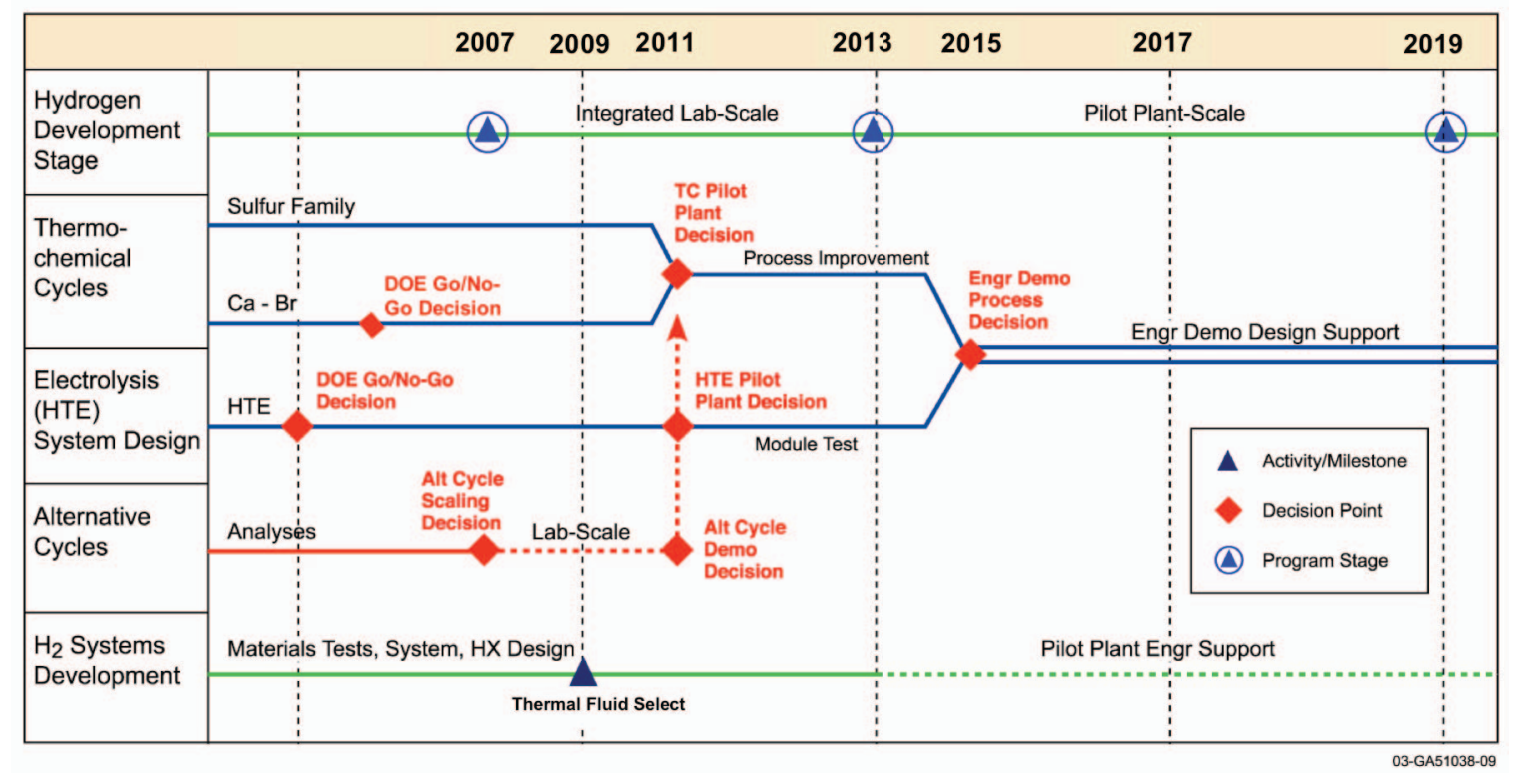

Figure 1. DOE Nuclear Hydrogen Initiative Project Schedule (Fall 2006) 


\section{SET OF TECHNICAL ISSUES}

The list of known System Interface and Supporting Systems technical issues is shown in Table 1. The focus of the list is on the near-term leading up to the 2011 pilot-scale selection in Figure 1. The list is organized under six headings. These headings are: "1. Use of Liquid Salt for Intermediate Heat Transport Loop", "2. Use of Helium for Intermediate Heat Transport Loop", "3. General Materials and Components", "4. Balance-of-Plant and Infrastructure", "5. Safety", and " 6 . General Operations." The column on the right-hand-side of the table indicates when the technical issue must be resolved to provide the highest quality, lowest risk recommendations to the larger project concerning pilot-plant down selects, overall system designs, and safety. By 2011, the DOE NHI will begin a transition period from nearly pure research and development activities to an organized construction and operation project with a sizeable industrial component. When that happens, research of the technical issues listed below may continue, but the constraints on equipment designs, plant layouts, and other considerations will become more fixed and more costly to alter. Therefore, research money is best directed to solving these issues within the prescribed time instead of waiting until design options have become more limited and resolution of unforeseen problems might be more costly to obtain.

Table 1. Set of Technical Issues

\begin{tabular}{|c|l|c|}
\hline Number & \multicolumn{1}{|c|}{ Description } & Needed by \\
\hline 1. Use of Liquid Salt for Intermediate Heat Transport Loop & 2009 \\
\hline 1. & $\begin{array}{l}\text { Determine suitability of liquid salt for the NGNP intermediate } \\
\text { loop and provide recommendations for/against its use in the } \\
\text { engineering-scale demonstration. }\end{array}$ & 2009 \\
\hline 1.1 & $\begin{array}{l}\text { Compare liquid salt intermediate heat transport loop to helium } \\
\text { heat transport loop (physical sizes, temperature/pressure } \\
\text { distributions, characteristics, materials, equipment, energy } \\
\text { costs, etc.) }\end{array}$ & 2009 \\
\hline 1.2 & $\begin{array}{l}\text { Develop system understanding of liquid salt intermediate heat } \\
\text { transport loop with necessary support systems (design } \\
\text { concepts, steady-state modeling, description of start-up, } \\
\text { shutdown, off-normal behaviors and responses, etc.). }\end{array}$ & 2009 \\
\hline 1.4 & $\begin{array}{l}\text { Determine redox control technique(s) or corrosion prevention } \\
\text { methods/procedures for chosen salt(s) in order to minimize } \\
\text { corrosion of intermediate loop containment/devices. }\end{array}$ & $\begin{array}{l}\text { Recommend heat exchanger designs for a He/Salt IHX and } \\
\text { determine implications of using liquid salt on design of } \\
\mathrm{H}_{2} \text { SO } \mathrm{O}_{4} \text { decomposer and related process heat exchangers. }\end{array}$ \\
\hline 1.5 & $\begin{array}{l}\text { Recommend best candidate salt/structural material sets for use } \\
\text { in the intermediate heat transport loop. }\end{array}$ & 2008 \\
\hline 1.6 & $\begin{array}{l}\text { Measure liquid salt data and corrosion data, as needed, to fill } \\
\text { in "holes." Data must be collected in priority order. }\end{array}$ & 2008 \\
\hline
\end{tabular}




\begin{tabular}{|c|c|c|}
\hline Number & Description & Needed by \\
\hline 1.7 & $\begin{array}{l}\text { Assemble liquid salt data and materials corrosion data from } \\
\text { literature sources and identify and prioritize physical data } \\
\text { "holes." }\end{array}$ & 2007 \\
\hline \multicolumn{3}{|c|}{ 2. Use of Helium for Intermediate Heat Transport Loop } \\
\hline 2. & $\begin{array}{l}\text { Develop system understanding of a practical helium } \\
\text { intermediate heat transport loop to support intermediate heat } \\
\text { transport fluid down-select (pipe configuration, length } \\
\text { limitations, pressure drops, energy consumption, etc.) }\end{array}$ & 2009 \\
\hline 2.1 & $\begin{array}{l}\text { Determine effects of helium environments (commercial } \\
\text { purity) on IHX candidate materials and recommend } \\
\text { conditions to minimize corrosion/erosion. }\end{array}$ & 2009 \\
\hline 2.2 & $\begin{array}{l}\text { Model and test internal pipe insulation materials and methods } \\
\text { for helium transport pipes. }\end{array}$ & 2008 \\
\hline 2.3 & $\begin{array}{l}\text { Recommend heat exchanger designs/materials for } \mathrm{He} / \mathrm{He} \mathrm{IHX} \\
\text { and process heat exchangers that are connected to the } \\
\text { intermediate loop (excluding the } \mathrm{H}_{2} \mathrm{SO}_{4} \text { decomposer). }\end{array}$ & 2008 \\
\hline \multicolumn{3}{|c|}{ 3. General Materials and Components } \\
\hline 3. & $\begin{array}{l}\text { Provide detailed list of candidate component designs or } \\
\text { concepts and suitably matched materials for use in pilot-scale } \\
\text { demonstration plant(s) and independent pilot-scale testing. }\end{array}$ & 2011 \\
\hline 3.1 & $\begin{array}{l}\text { Examine use of high performance alloys and ceramics for } \\
\text { IHX use (not code approved) }\end{array}$ & 2009 \\
\hline 3.2 & Initiate assembled heat exchanger tests in the laboratory. & 2009 \\
\hline 3.3 & $\begin{array}{l}\text { Obtain high-temp creep, mechanical property data, } \\
\text { permeability, manufacturing methods and so on to fill in data } \\
\text { "holes" for IHX-suitable materials (code approved or nearly } \\
\text { code-approved materials only). }\end{array}$ & 2008 \\
\hline 3.4 & $\begin{array}{l}\text { Obtain high-temp mechanical properties, permeability, and } \\
\text { identify manufacturing methods, as needed, for candidate } \\
\text { process heat exchanger materials to supplement heat } \\
\text { exchanger design efforts. }\end{array}$ & 2008 \\
\hline 3.5 & Identify designs and materials for high-temp oxygen cooler. & 2008 \\
\hline 3.6 & $\begin{array}{l}\text { Perform corrosion testing of structural materials (metals, } \\
\text { ceramics, cladded/coated samples) exposed to liquid/vapor } \\
\mathrm{H}_{2} \mathrm{SO}_{4} \text { and related chemicals. }\end{array}$ & On-going \\
\hline 3.7 & $\begin{array}{l}\text { Perform corrosion testing of structural materials (metals, } \\
\text { ceramics, cladded/coated samples) exposed to HIx solutions } \\
\text { under flow conditions. }\end{array}$ & On-going \\
\hline 3.8 & $\begin{array}{l}\text { Review and assess components shown on hydrogen } \\
\text { production process flow sheets (S-I, high-temp electrolysis, } \\
\text { and alternative processes if needed) for technical readiness. }\end{array}$ & $\begin{array}{l}2007 \\
2008 \\
2009 \\
2010 \\
2011\end{array}$ \\
\hline
\end{tabular}




\begin{tabular}{|c|c|c|}
\hline Number & Description & Needed by \\
\hline 3.9 & $\begin{array}{l}\text { Revise the NHI Materials and Components Qualification Plan } \\
\text { as needed to make it more usable by the program. }\end{array}$ & $\begin{array}{l}2007 \\
2008 \\
2009 \\
2010\end{array}$ \\
\hline 3.10 & $\begin{array}{l}\text { Develop suitable database and begin implementation of the } \\
\text { NHI Materials and Components Qualification Plan across the } \\
\text { larger research program. }\end{array}$ & 2007 \\
\hline 3.11 & Develop NHI Materials and Components Qualification Plan & 2007 \\
\hline \multicolumn{3}{|c|}{ 4. Balance-of-Plant and Infrastructure } \\
\hline 4. & $\begin{array}{l}\text { Determine baseline balance-of-plant and infrastructure } \\
\text { configurations of candidate pilot-scale hydrogen production } \\
\text { plants. }\end{array}$ & 2011 \\
\hline 4.1 & $\begin{array}{l}\text { Examine physical and spatial relationships between HTE } \\
\text { plant units and the intermediate heat transport loop, and } \\
\text { determine minimum heat transfer distances while maximizing } \\
\text { distance between nuclear plant and hydrogen } \\
\text { production/storage units. }\end{array}$ & 2009 \\
\hline 4.2 & $\begin{array}{l}\text { Examine physical and spatial relationships between S-I plant } \\
\text { units and the intermediate heat transport loop, and determine } \\
\text { minimum heat transfer distances while maximizing distance } \\
\text { between nuclear plant and hydrogen production/storage units. }\end{array}$ & 2008 \\
\hline 4.3 & $\begin{array}{l}\text { Identify environmental permitting requirements for S-I and } \\
\text { HTE plants and initiate permitting activities (as needed). }\end{array}$ & 2008 \\
\hline 4.4 & $\begin{array}{l}\text { Identify necessity, operational requirements and equipment } \\
\text { options for auxiliary heat source/sink for intermediate loop. }\end{array}$ & 2008 \\
\hline \multicolumn{3}{|c|}{ 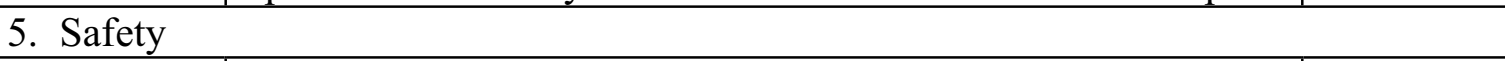 } \\
\hline 5. & $\begin{array}{l}\text { Submit detailed safety strategy containing defenses-in-depth, } \\
\text { risk-based features, and operational recommendations to } \\
\text { maximize safety of the combined nuclear plant/hydrogen } \\
\text { plant. }\end{array}$ & 2011 \\
\hline 5.1 & $\begin{array}{l}\text { Perform transient analyses of combined plant to look for } \\
\text { potential safety problems that would not be present under } \\
\text { steady-state operating conditions. }\end{array}$ & 2010 \\
\hline 5.2 & $\begin{array}{l}\text { Determine tritium permeation and control strategies to } \\
\text { minimize concentrations of tritium in the hydrogen product } \\
\text { (must be coordinated with intermediate heat transport fluid } \\
\text { selection). }\end{array}$ & 2010 \\
\hline 5.3 & $\begin{array}{l}\text { Examine chemical industry safety "best practices" and begin } \\
\text { incorporation of usable information into the DOE NHI R\&D } \\
\text { plant design process. }\end{array}$ & 2008 \\
\hline 5.4 & $\begin{array}{l}\text { Develop or identify high-temp isolation valve designs or } \\
\text { concepts for further testing (applicable to IHX). }\end{array}$ & 2008 \\
\hline
\end{tabular}




\begin{tabular}{|c|l|c|}
\hline Number & \multicolumn{1}{|c|}{ Description } & Needed by \\
\hline 6. General Operations & 2009 \\
\hline 6. & $\begin{array}{l}\text { Develop steady-state and transient modeling capabilities for } \\
\text { combined system that are applicable for NRC licensing }\end{array}$ & 2009 \\
\hline 6.1 & Incorporate economic evaluation capabilities into HyPEP. & 2008 \\
\hline 6.2 & $\begin{array}{l}\text { Complete steady-state HyPEP Model to include both S-I and } \\
\text { HTE processes. }\end{array}$ & $\begin{array}{l}\text { Develop transient modeling capabilities for the combined } \\
\text { plant that are suitable for safety and operations analysis and } \\
\text { the design of control system strategies. }\end{array}$ \\
\hline 6.4 & Complete beta testing of HyPEP model. & 2008 \\
\hline 6.5 & Complete alpha testing of HyPEP model. & 2007 \\
\hline
\end{tabular}

Table 2. Sequential Ordering of Technical Issues and Goals

\begin{tabular}{|c|c|}
\hline \multicolumn{2}{|l|}{2007} \\
\hline 1.7 & $\begin{array}{l}\text { Assemble liquid salt data and materials corrosion data from literature } \\
\text { sources and identify and prioritize physical data "holes." }\end{array}$ \\
\hline 3.8 & $\begin{array}{l}\text { Review and assess components shown on hydrogen production flow sheets } \\
\text { (S-I, high-temp electrolysis, and alternative processes, if needed) for } \\
\text { technical readiness. }\end{array}$ \\
\hline 3.9 & $\begin{array}{l}\text { Revise the NHI Materials and Components Qualification Plan, as needed, } \\
\text { to make it more usable by the program. }\end{array}$ \\
\hline 3.10 & $\begin{array}{l}\text { Develop suitable database and begin implementation of the NHI Materials } \\
\text { and Components Qualification Plan across the larger research program. }\end{array}$ \\
\hline 3.11 & Develop NHI Materials and Components Qualification plan. \\
\hline 6.5 & Complete alpha testing of HyPEP model. \\
\hline \multicolumn{2}{|r|}{ 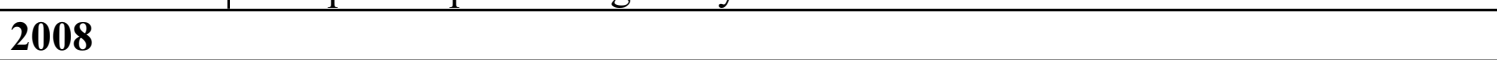 } \\
\hline 1.5 & $\begin{array}{l}\text { Recommend best candidate salt/structural material sets for use in the } \\
\text { intermediate heat transport loop. }\end{array}$ \\
\hline 1.6 & $\begin{array}{l}\text { Measure liquid salt data and corrosion data, as needed, to fill in "holes." } \\
\text { Data must be collected in priority order. }\end{array}$ \\
\hline 2.2 & $\begin{array}{l}\text { Model and test internal pipe insulation materials and methods for helium } \\
\text { transport pipes. }\end{array}$ \\
\hline 2.3 & $\begin{array}{l}\text { Recommend heat exchanger designs/materials for } \mathrm{He} / \mathrm{He} \mathrm{IHX} \text { and process } \\
\text { heat exchangers that are connected to the intermediate loop (excluding the } \\
\mathrm{H}_{2} \mathrm{SO}_{4} \text { decomposer). }\end{array}$ \\
\hline 3.3 & $\begin{array}{l}\text { Obtain high-temp creep, mechanical property data, permeability, } \\
\text { manufacturing methods and so on to fill in data "holes" for IHX-suitable } \\
\text { materials (code-approved or nearly code-approved materials only). }\end{array}$ \\
\hline 3.4 & $\begin{array}{l}\text { Obtain high-temp mechanical properties, permeability, and identify } \\
\text { manufacturing methods, as needed, for candidate process heat exchanger } \\
\text { materials to supplement heat exchanger design efforts. }\end{array}$ \\
\hline 3.5 & Identify designs and materials for high-temp oxygen cooler. \\
\hline
\end{tabular}




\begin{tabular}{|c|c|}
\hline 3.8 & $\begin{array}{l}\text { Review and assess components shown on hydrogen production process } \\
\text { flow sheets (S-I, high-temp electrolysis, and alternative processes, if } \\
\text { needed) for technical readiness. }\end{array}$ \\
\hline 3.9 & $\begin{array}{l}\text { Revise the NHI Materials and Components Qualification Plan as needed to } \\
\text { make it more usable by the Program. }\end{array}$ \\
\hline 4.2 & $\begin{array}{l}\text { Examine physical and spatial relationships between S-I plant units and the } \\
\text { intermediate heat transport loop, and determine minimum heat transfer } \\
\text { distances while maximizing distance between nuclear plant and hydrogen } \\
\text { production/storage units. }\end{array}$ \\
\hline 4.3 & $\begin{array}{l}\text { Identify environmental permitting requirements for S-I and HTE plants and } \\
\text { initiate permitting activities, as required. }\end{array}$ \\
\hline 4.4 & $\begin{array}{l}\text { Identify necessity, operating requirements and equipment options for } \\
\text { auxiliary heat source/sink for intermediate loop. }\end{array}$ \\
\hline 5.3 & $\begin{array}{l}\text { Examine chemical industry safety "best practices" and begin incorporation } \\
\text { of usable information into the DOE NHI R\&D pant design process. }\end{array}$ \\
\hline 5.4 & $\begin{array}{l}\text { Develop or identify high-temp isolation valve designs or concepts for } \\
\text { further testing (applicable to IHX). }\end{array}$ \\
\hline 6.2 & $\begin{array}{l}\text { Complete steady-state HyPEP Model to include both S-I and HTE } \\
\text { processes. }\end{array}$ \\
\hline 6.3 & $\begin{array}{l}\text { Develop transient modeling capabilities for the combined plant that are } \\
\text { suitable for safety and operational analysis and the design of control system } \\
\text { strategies. }\end{array}$ \\
\hline 6.4 & Complete beta testing of the HyPEP model. \\
\hline \multicolumn{2}{|l|}{2009} \\
\hline 1. & $\begin{array}{l}\text { Determine suitability of liquid salt for the NGNP intermediate loop and } \\
\text { provide recommendations for/against its use in the engineering-scale } \\
\text { demonstration. }\end{array}$ \\
\hline 1.1 & $\begin{array}{l}\text { Compare liquid salt intermediate heat transport loop to helium heat } \\
\text { transport loop (physical sizes, temperature/pressure distribution, } \\
\text { characteristics, materials, equipment, energy costs, etc.) }\end{array}$ \\
\hline 1.2 & $\begin{array}{l}\text { Develop system understanding of liquid salt intermediate heat transport } \\
\text { loop with necessary support systems (design concepts, steady-state } \\
\text { modeling, description of start-up, shutdown, off-normal behaviors and } \\
\text { responses, etc.) }\end{array}$ \\
\hline 1.3 & $\begin{array}{l}\text { Determine redox control technique(s) or corrosion prevention } \\
\text { methods/procedures for chosen salt(s) in order to minimize corrosion of } \\
\text { intermediate loop containment/devices. }\end{array}$ \\
\hline 1.4 & $\begin{array}{l}\text { Recommend heat exchanger designs for } \mathrm{He} / \mathrm{Salt} \mathrm{IHX} \text { and determine } \\
\text { implications of using liquid salt on design of } \mathrm{H}_{2} \mathrm{SO}_{4} \text { decomposer and } \\
\text { related process heat exchangers. }\end{array}$ \\
\hline 2. & $\begin{array}{l}\text { Develop system-level understanding of a practical helium intermediate heat } \\
\text { transport loop to support intermediate heat transfer fluid down-select (pipe } \\
\text { configuration, length, limitations, pressure drops, energy consumption, } \\
\text { etc.) }\end{array}$ \\
\hline 2.1 & Determine effects of helium environments (commercial purity) on IHX \\
\hline
\end{tabular}




\begin{tabular}{|c|c|}
\hline & $\begin{array}{l}\text { candidate materials and recommend conditions to minimize } \\
\text { corrosion/erosion. }\end{array}$ \\
\hline 3.1 & $\begin{array}{l}\text { Examine use of high performance alloys and ceramics for IHX use (not } \\
\text { code approved). }\end{array}$ \\
\hline 3.2 & Initiate assembled heat exchanger testing in the laboratory. \\
\hline 3.8 & $\begin{array}{l}\text { Review and assess components shown on hydrogen production flow sheets } \\
\text { (S-I, high-temp electrolysis, and alternative processes if needed) for } \\
\text { technical readiness. }\end{array}$ \\
\hline 3.9 & $\begin{array}{l}\text { Revise the NHI Materials and Components Qualification Plan as needed to } \\
\text { make it more usable by the program. }\end{array}$ \\
\hline 4.1 & $\begin{array}{l}\text { Examine physical and spatial relationships between HTE plant units and } \\
\text { the intermediate heat transport loop, and determine minimum heat transfer } \\
\text { distances while maximizing distance between nuclear plant and hydrogen } \\
\text { production/storage units. }\end{array}$ \\
\hline 6. & $\begin{array}{l}\text { Develop steady-state and transient modeling capabilities for combined } \\
\text { system that are applicable for NRC licensing. }\end{array}$ \\
\hline 6.1 & Incorporate economic evaluation capability into HyPEP. \\
\hline \multicolumn{2}{|l|}{2010} \\
\hline 3.8 & $\begin{array}{l}\text { Review and assess components shown on hydrogen production process } \\
\text { flow sheets (S-I, HTE and alternative processes if needed) for technical } \\
\text { readiness. }\end{array}$ \\
\hline 3.9 & $\begin{array}{l}\text { Revise the NHI Materials and Components Qualification Plan as needed to } \\
\text { make it more usable by the program. }\end{array}$ \\
\hline 5.1 & $\begin{array}{l}\text { Perform transient analysis of combined plant to look for potential safety } \\
\text { problems that would not be present under steady-state operating conditions. }\end{array}$ \\
\hline 5.2 & $\begin{array}{l}\text { Determine tritium permeation and control strategies to minimize } \\
\text { concentrations of tritium in the hydrogen product (must be coordinated } \\
\text { with the intermediate heat transport fluid selection). }\end{array}$ \\
\hline \multicolumn{2}{|r|}{ e } \\
\hline 3. & $\begin{array}{l}\text { Provide detailed set of candidate component designs or concepts and } \\
\text { suitably matched materials for use in pilot-scale demonstration plant(s) and } \\
\text { independent pilot-scale testing. }\end{array}$ \\
\hline 3.8 & $\begin{array}{l}\text { Review and assess components shown on hydrogen production flow sheets } \\
\text { (S-I, HTE and alternative processes if needed) for technical readiness. }\end{array}$ \\
\hline 4. & $\begin{array}{l}\text { Determine baseline balance-of-plant and infrastructure configurations of } \\
\text { candidate pilot-scale hydrogen production plants. }\end{array}$ \\
\hline 5. & $\begin{array}{l}\text { Submit detailed safety strategy containing defense-in-depth, risk-based } \\
\text { features, and operational recommendations to maximize safety of the } \\
\text { combined plant. }\end{array}$ \\
\hline
\end{tabular}




\section{SET OF REPORTS AND PROJECTS}

The list of past and on-going System Interface and Supporting Systems projects is shown in Table 3. The table provides the project date, the description, and origin (location) for the project. Where reports or documents have been written, report or document titles are provided under the description heading. Where work is underway and reports or project documents have yet to be issues, the work package or NERI project title is provided under the description heading instead.

Table 3. Set of System Interface and Supporting Systems Projects/Reports

\begin{tabular}{|c|c|c|}
\hline Identifier & Description & Origin \\
\hline \multicolumn{3}{|l|}{ FY 2004} \\
\hline UNLV 1Q 2004 & UNLV HTHX Project Quarterly Report, 1Q FY04 & UNLV \\
\hline UNLV 2Q_2004 & UNLV HTHX Project Quarterly Report, 2Q FY04 & UNLV \\
\hline UNLV 3Q_2004 & UNLV HTHX Project Quarterly Report, 3Q FY04 & UNLV \\
\hline UNLV 4Q_2004 & UNLV HTHX Project Quarterly Report, 4Q FY04 & UNLV \\
\hline $\begin{array}{l}\text { ANL W7500- } \\
001-E S-00\end{array}$ & Reactor/Process Interface Requirements & ANL-W \\
\hline $\begin{array}{l}\text { ANL W7500- } \\
002-E S-00\end{array}$ & $\begin{array}{l}\text { Reactor/Process Interface Heat Exchanger and Intermediate } \\
\text { Loop Technical Issues }\end{array}$ & ANL-W \\
\hline $\begin{array}{l}\text { ANL W7500- } \\
003-E S-00\end{array}$ & $\begin{array}{l}\text { Balance of Plant Requirements for a Nuclear Hydrogen } \\
\text { Production Plant }\end{array}$ & ANL-W \\
\hline $\begin{array}{l}\text { INEEL EXT-04- } \\
01791\end{array}$ & $\begin{array}{l}\text { Infrastructure Requirements for a Nuclear Hydrogen Pilot } \\
\text { Plant }\end{array}$ & INEEL \\
\hline \multicolumn{3}{|l|}{ FY 2005} \\
\hline UNLV 1Q_2005 & UNLV HTHX Project Quarterly Report, 1Q FY05 & UNLV \\
\hline UNLV 2Q_2005 & UNLV HTHX Project Quarterly Report, 2Q FY05 & UNLV \\
\hline UNLV 3Q_2005 & UNLV HTHX Project Quarterly Report, 3Q FY05 & UNLV \\
\hline UNLV 4Q_2005 & UNLV HTHX Project Quarterly Report, 4Q FY05 & UNLV \\
\hline UNLV 2005 & UNLV HTHX Project FY 2005 Year-End Report & UNLV \\
\hline $\begin{array}{l}\text { INL EXT-05- } \\
00137\end{array}$ & $\begin{array}{l}\text { An Engineering Analysis for Separation Requirements of a } \\
\text { Hydrogen Production Plant and High-Temperature Nuclear } \\
\text { Reactor, Revision } 0\end{array}$ & INL \\
\hline $\begin{array}{l}\text { INL EXT-05- } \\
00453\end{array}$ & $\begin{array}{l}\text { Thermal-Hydraulic Analysis of Heat Transfer Fluid } \\
\text { Requirements and Characteristics for Coupling a Hydrogen } \\
\text { Production Plant to a High-Temperature Nuclear Reactor }\end{array}$ & INL \\
\hline $\begin{array}{l}\text { INL EXT-05- } \\
00690\end{array}$ & $\begin{array}{l}\text { Engineering Analysis of Intermediate Loop and Process } \\
\text { Heat Exchanger Requirements to Include Configuration } \\
\text { Analysis and Materials Needs }\end{array}$ & INL \\
\hline NERI 05-032 & $\begin{array}{l}\text { Silicon Carbide Ceramics for Compact Heat Exchangers (3- } \\
\text { year project) }\end{array}$ & $\begin{array}{c}\text { Johns Hopkins } \\
\text { University }\end{array}$ \\
\hline $\begin{array}{l}\text { NERI } 05-154 \\
1 \mathrm{Q}\end{array}$ & $\begin{array}{l}\text { Molten Salt Transport Loop: Materials Corrosion and Heat } \\
\text { Transfer Phenomena, } 1^{\text {st }} \text { Quarterly Report }\end{array}$ & U of Wis. \\
\hline $\begin{array}{l}\text { NERI } 05-154 \\
2 Q\end{array}$ & $\begin{array}{l}\text { Molten Salt Transport Loop: Materials Corrosion and Heat } \\
\text { Transfer Phenomena, } 2^{\text {nd }} \text { Quarterly Report }\end{array}$ & U of Wis. \\
\hline
\end{tabular}




\begin{tabular}{|c|c|c|}
\hline Identifier & Description & Origin \\
\hline \multicolumn{3}{|l|}{ FY 2006} \\
\hline UNLV 1Q_2006 & UNLV HTHX Project Quarterly Report, 1Q FY06 & UNLV \\
\hline UNLV 2Q_2006 & UNLV HTHX Project Quarterly Report, 2Q FY06 & UNLV \\
\hline UNLV 3Q 2006 & UNLV HTHX Project Quarterly Report, 3Q FY06 & UNLV \\
\hline UNLV 4Q_2006 & UNLV HTHX Project Quarterly Report, 4Q FY06 & UNLV \\
\hline $\begin{array}{l}\text { INL EXT-06- } \\
11232\end{array}$ & $\begin{array}{l}\text { Balance of Plant Requirements for a Nuclear Hydrogen } \\
\text { Plant, Revision } 1\end{array}$ & INL \\
\hline $\begin{array}{l}\text { INL EXT-06- } \\
11482\end{array}$ & $\begin{array}{l}\text { Assessment of Codes and Standards Applicable to a } \\
\text { Hydrogen Production Plant Coupled to a Nuclear Reactor }\end{array}$ & INL \\
\hline $\begin{array}{l}\text { INL EXT-05- } \\
00137 \text { Rev. } 1\end{array}$ & $\begin{array}{l}\text { An Engineering Analysis for Separation Requirements of a } \\
\text { Hydrogen Production Plant and High-Temperature Nuclear } \\
\text { Reactor }\end{array}$ & INL \\
\hline $\begin{array}{l}\text { INL EXT-06- } \\
11725\end{array}$ & HyPEP FY06 Report: Models and Methods & $\begin{array}{l}\text { INL, ANL, } \\
\text { KAERI }\end{array}$ \\
\hline $\begin{array}{l}\text { ORNL TM-2006 } \\
563\end{array}$ & NHI Materials and Components Development Plan & ORNL, INL \\
\hline $\begin{array}{l}\text { ORNL TM-2006 } \\
69\end{array}$ & $\begin{array}{l}\text { Assessment of Candidate Molten Salt Coolants for the } \\
\text { NGNP/NHI Heat-Transfer Loop }\end{array}$ & ORNL \\
\hline NERI 05-032 & $\begin{array}{l}\text { Silicon Carbide Ceramics for Compact Heat Exchangers (3- } \\
\text { year project) }\end{array}$ & $\begin{array}{l}\text { Johns Hopkins } \\
\text { University }\end{array}$ \\
\hline $\begin{array}{l}\text { NERI 05-154 } \\
\text { 3Q }\end{array}$ & $\begin{array}{l}\text { Molten Salt Transport Loop: Materials Corrosion and Heat } \\
\text { Transfer Phenomena, } 3^{\text {rd }} \text { Quarterly Report }\end{array}$ & U of Wis. \\
\hline $\begin{array}{l}\text { NERI } 05-154 \\
\text { Y1 }\end{array}$ & $\begin{array}{l}\text { Molten Salt Transport Loop: Materials Corrosion and Heat } \\
\text { Transfer Phenomena, Year } 1 \text { Report }\end{array}$ & U of Wis. \\
\hline $\begin{array}{l}\text { NERI } 05-154 \\
5 \mathrm{Q}\end{array}$ & $\begin{array}{l}\text { Molten Salt Transport Loop: Materials Corrosion and Heat } \\
\text { Transfer Phenomena, } 5^{\text {th }} \text { Quarterly Report }\end{array}$ & U of Wis. \\
\hline $\begin{array}{l}\text { NERI } 05-154 \\
6 \mathrm{Q}\end{array}$ & $\begin{array}{l}\text { Molten Salt Transport Loop: Materials Corrosion and Heat } \\
\text { Transfer Phenomena, } 6^{\text {th }} \text { Quarterly Report }\end{array}$ & U of Wis. \\
\hline NERI 06-024 & $\begin{array}{l}\text { Ni-Si Alloys for the S-I Reactor/Hydrogen Production } \\
\text { Process Interface (3-year project) }\end{array}$ & $\begin{array}{l}\text { U of Mo and } \\
\text { INL }\end{array}$ \\
\hline NERI 06-041 & $\begin{array}{l}\text { Dynamic Simulation and Optimization of Nuclear Hydrogen } \\
\text { Production Systems (3-year project) }\end{array}$ & MIT \\
\hline \multicolumn{3}{|c|}{ 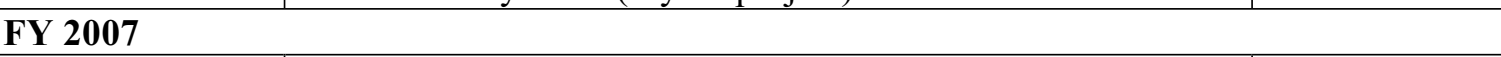 } \\
\hline N-AN07SS0101 & $\begin{array}{l}\text { Steady State and Transient Modeling of Combined Nuclear } \\
\text { Hydrogen Plant }\end{array}$ & ANL \\
\hline N-ID07SS0101 & UNLV NHI Materials Support & UNLV \\
\hline N-ID07SS0102 & UNLV NHI Momentum/Heat/Mass Transfer & UNLV \\
\hline N-ID07SS0103 & UNLV NHI Liquid Salt Systems & UNLV \\
\hline N-ID07SS0104 & UNLV NHI Materials/Surface Characterization & UNLV \\
\hline N-ID07SS0105 & UNLV NHI Chemistry Support & UNLV \\
\hline N-ID07SS0106 & $\begin{array}{l}\text { Measurement of Mechanical Alloy Properties at UNLV - } \\
\text { FY06 Carryover }\end{array}$ & UNLV \\
\hline N-ID07SS0107 & $\begin{array}{l}\text { Corrosion and Crack Growth Studies in HIx Solutions at } \\
\text { General Atomics - FY06 Carryover }\end{array}$ & GA \\
\hline N-ID07SS0108 & $\begin{array}{l}\text { Numerical Analysis of Advanced Heat Exchanger Concepts } \\
\text { at UNV - FY06 Carryover }\end{array}$ & UNLV \\
\hline N-ID07SS0109 & $\begin{array}{l}\text { C-SiC Materials for HTHX's at UC-Berkeley - FY06 } \\
\text { Carryover }\end{array}$ & $\mathrm{UCB}$ \\
\hline
\end{tabular}




\begin{tabular}{|l|l|c|}
\hline \multicolumn{1}{|c|}{ Identifier } & \multicolumn{1}{|c|}{ Description } & Origin \\
\hline N-ID07SS0110 & $\begin{array}{l}\text { Ceramic Heat Exchanger Development for Application to } \\
\text { NHI Hydrogen Production Processes (FY06 Carryover) }\end{array}$ & Ceramatec \\
\hline N-ID07SS0111 & $\begin{array}{l}\text { Ceramic Heat Exchanger Development for Application to } \\
\text { NHI Hydrogen Production Processes (FY07 Bridge } \\
\text { Package) }\end{array}$ & Ceramatec \\
\hline N-ID07SS0112 & $\begin{array}{l}\text { UNLV RF High Temperature Heat Exchanger Project - } \\
\text { FY06 Carryover }\end{array}$ & UNLV \\
\hline N-ID07SS0113 & $\begin{array}{l}\text { The Development of Self-Catalytic Materials for } \\
\text { Thermochemical Water Splitting Using the Sulfur-Iodine } \\
\text { Process }\end{array}$ & MIT \\
\hline N-IN07SS0101 & $\begin{array}{l}\text { Steady-State and Transient Modeling of Combined Nuclear } \\
\text { Hydrogen Plant }\end{array}$ & INL \\
\hline N-IN07SS0102 & $\begin{array}{l}\text { Technical Director and Project Management Support for the } \\
\text { DOE NHI }\end{array}$ & INL \\
\hline N-OR07SS0101 & Development of NHI Materials and Components Test Plan & ORNL \\
\hline NERI 05-032 & $\begin{array}{l}\text { Silicon Carbide Ceramics for Compact Heat Exchangers (3- } \\
\text { year project) }\end{array}$ & $\begin{array}{c}\text { Johns Hopkins } \\
\text { University }\end{array}$ \\
\hline NERI 05-154 & $\begin{array}{l}\text { Molten Salt Transport Loop: Materials Corrosion and Heat } \\
\text { Transfer Phenomena (3-year project) }\end{array}$ & U of Wis. \\
\hline NERI 06-024 & $\begin{array}{l}\text { Ni-Si Alloys for the S-I Reactor/Hydrogen Production } \\
\text { Process Interface (3-year project) }\end{array}$ & $\begin{array}{l}\text { U of Mo and } \\
\text { INL }\end{array}$ \\
\hline NERI 06-041 & $\begin{array}{l}\text { Dynamic Simulation and Optimization of Nuclear Hydrogen } \\
\text { Production Systems (3-year project) }\end{array}$ & MIT \\
\hline
\end{tabular}




\section{MAPPING OF PROJECTS TO TECHNICAL ISSUES}

Table 4 shows the mapping of projects to technical issues. The project identifiers are the same ones used in Tables 2 and 3 to differentiate between projects. If the project identifier box is empty in Table 4, then no projects have yet been pursued to solve the technical issue. The "Resolved?" indicator shows whether the technical issue has been resolved or will be resolved this fiscal year. The "Year Needed" column shows when the particular technical issue must be solved in order to support the construction and operation of pilot-scale and engineering-scale equipment. If the "Year Needed" box is filled with an "On-going" indicator, then the work is expected to be ongoing and does not have a defined resolution.

Table 4. Map of Projects and Issues

\begin{tabular}{|c|c|c|c|}
\hline $\begin{array}{l}\text { Issue } \\
\text { Number }\end{array}$ & Project Identifier & $\begin{array}{l}\text { Resolved } \\
\text { in FY07? }\end{array}$ & $\begin{array}{l}\text { Year } \\
\text { Needed }\end{array}$ \\
\hline \multicolumn{4}{|c|}{ 1. Use of Liquid Salt for Intermediate Heat Transport Loop } \\
\hline 1. & ANL W7500-002-ES-00 & No & 2009 \\
\hline 1.1 & INL EXT-05-00453 & No & 2009 \\
\hline 1.2 & INL EXT-05-00453, N-ID07SS0103 & No & 2009 \\
\hline 1.3 & UNLV $(2,3,4) \mathrm{Q} 2006$, N-ID07SS0103 & No & 2009 \\
\hline 1.4 & $\begin{array}{l}\text { UNLV }(1,2,3,4) \mathrm{Q} \text { 2004, UNLV }(1,2,3,4) \\
\text { Q2005, UNLV 2005, UNLV }(1,2,3,4) \text { Q_2006, N- } \\
\text { ID07SS0109 }\end{array}$ & No & 2009 \\
\hline 1.5 & ORNL TM-2006 69, N-ID07SS0103 & No & 2008 \\
\hline 1.6 & NERI 05-154 & No & 2008 \\
\hline 1.7 & $\begin{array}{l}\text { NERI 05-154 }(1,2,3,5,6) \mathrm{Q}, \mathrm{NERI} 05-154 \mathrm{Y1} \text {, } \\
\text { ORNL TM-2006 69, N-ID07SS0103 }\end{array}$ & Yes & 2007 \\
\hline \multicolumn{4}{|c|}{ 2. Use of Helium for Intermediate Heat Transport Loop } \\
\hline 2. & $\begin{array}{l}\text { ANL W7500-002-ES-00, INL EXT-05-00453, } \\
\text { INL EXT-05-00690 }\end{array}$ & No & 2009 \\
\hline 2.1 & N-ID07SS0101 & No & 2009 \\
\hline 2.2 & N-ID07SS0102 & No & 2008 \\
\hline 2.3 & $\begin{array}{l}\text { UNLV (1,2,3,4)Q_2004, UNLV (1,2,3,4)Q_2005, } \\
\text { UNLV 2005, UNLV (1,2,3,4)Q_2006, INL EXT- } \\
\text { 05-00690, N-ID07SS0102, N-ID07SS0108, N- } \\
\text { ID07SS0110 }\end{array}$ & No & 2008 \\
\hline \multicolumn{4}{|c|}{ 3. General Materials and Components } \\
\hline 3. & N-IN07SS0102, N-OR07SS0101 & No & 2011 \\
\hline 3.1 & $\begin{array}{l}\text { UNLV }(1,2,3,4) Q \_2004, \text { UNLV }(1,2,3,4) Q \_2005 \text {, } \\
\text { UNLV 2005, UNLV }(1,2,3,4) Q \_2006 \text {, INL EXT- } \\
\text { 05-00453, INL EXT-05-00690 }\end{array}$ & No & 2009 \\
\hline 3.2 & & No & 2009 \\
\hline
\end{tabular}




\begin{tabular}{|c|c|c|c|}
\hline $\begin{array}{l}\text { Issue } \\
\text { Number }\end{array}$ & Project Identifier & $\begin{array}{l}\text { Resolved } \\
\text { in FY07? }\end{array}$ & $\begin{array}{c}\text { Year } \\
\text { Needed }\end{array}$ \\
\hline 3.3 & 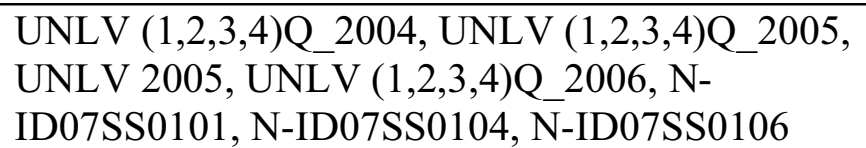 & No & 2008 \\
\hline 3.4 & $\begin{array}{l}\text { UNLV }(1,2,3,4) Q=2004, \text { UNLV }(1,2,3,4) Q \_2005 \text {, } \\
\text { UNLV 2005, UNLV (1,2,3,4)Q_2006, N- } \\
\text { ID07SS0101, N-ID07SS0107, N-ID07SS0109, N- } \\
\text { ID07SS01110, N-ID07SS0111, N-ID07SS0113, } \\
\text { NERI 05-032, NERI 06-024 }\end{array}$ & No & 2008 \\
\hline 3.5 & $\begin{array}{l}\text { UNLV }(1,2,3,4) Q \text { 2006, N-ID07SS0101, N- } \\
\text { ID07SS0110, N-ID07SS0111 }\end{array}$ & No & 2008 \\
\hline 3.6 & $\begin{array}{l}\text { UNLV }(1,2,3,4) Q \_2006, \text { N-ID07SS0110, N- } \\
\text { ID07SS0111 }\end{array}$ & No & $\begin{array}{l}\text { On- } \\
\text { going }\end{array}$ \\
\hline 3.7 & $\begin{array}{l}\text { UNLV }(1,2,3,4) Q \_2004, \text { UNLV }(1,2,3,4) Q \_2005 \text {, } \\
\text { UNLV 2005, UNLV (1,2,3,4)Q_2006, N- } \\
\text { ID07SS0101, N-ID07SS0104, N-ID07SS0105, N- } \\
\text { ID07SS0107 }\end{array}$ & No & $\begin{array}{l}\text { On- } \\
\text { going }\end{array}$ \\
\hline 3.8 & N-IN07SS0102, N-OR07SS0101 & No & $\begin{array}{l}2007, \\
2008, \\
2009 \\
2010 \\
2011\end{array}$ \\
\hline 3.9 & N-IN07SS0102, N-OR07SS0101 & No & $\begin{array}{l}2007, \\
2008, \\
2009 \\
2010\end{array}$ \\
\hline 3.10 & N-IN07SS0102 & Yes & 2007 \\
\hline 3.11 & N-IN07SS0102, N-OR07SS0101 & Yes & 2007 \\
\hline \multicolumn{4}{|c|}{ 4. Balance-of-Plant and Infrastructure } \\
\hline 4. & $\begin{array}{l}\text { INEEL EXT-04-01791, ANL W7500-001-ES-00, } \\
\text { INL EXT-06-11232 }\end{array}$ & No & 2011 \\
\hline 4.1 & & No & 2009 \\
\hline 4.2 & INL EXT-05-00137, INL EXT-05-00137 Rev. 1 & No & 2008 \\
\hline 4.3 & & No & 2008 \\
\hline 4.4 & ANL W7500-003-ES-00 & No & 2008 \\
\hline \multicolumn{4}{|l|}{ 5. Safety } \\
\hline 5. & ANL W7500-002-ES-00, INL EXT-06-11482 & No & 2011 \\
\hline 5.1 & N-AN07SS0101, N-IN07SS0101 & No & 2008 \\
\hline 5.2 & & No & 2008 \\
\hline 5.3 & INL EXT-05-00137 Rev. 1 & No & 2008 \\
\hline 5.4 & & No & 2008 \\
\hline
\end{tabular}




\begin{tabular}{|c|l|c|c|}
\hline $\begin{array}{c}\text { Issue } \\
\text { Number }\end{array}$ & \multicolumn{1}{|c|}{ Project Identifier } & $\begin{array}{c}\text { Resolved } \\
\text { in FY07? }\end{array}$ & $\begin{array}{c}\text { Year } \\
\text { Needed }\end{array}$ \\
\hline 6. General Operations & No & 2009 \\
\hline 6. & $\begin{array}{l}\text { INL EXT-06-11725, N-AN07SS0101, N- } \\
\text { IN07SS0101 }\end{array}$ & No & 2009 \\
\hline 6.1 & \multicolumn{1}{|c|}{} & 2008 \\
\hline 6.2 & $\begin{array}{l}\text { INL EXT-06-11725, N-AN07SS0101, N- } \\
\text { IN07SS0101 }\end{array}$ & No & 2008 \\
\hline 6.3 & N-AN07SS0101, NERI 06-041 & No & 2008 \\
\hline 6.4 & & Yes & 2007 \\
\hline 6.5 & N-IN07SS0101 &
\end{tabular}




\section{ASSESSMENT OF THE MAP}

Since FY 2006 when a mapping of technical issues to accomplished work was first performed (Sherman, 2006), the NHI timelines and priorities have undergone significant revision, and the need to coordinate closely with the newly created Next Generation Nuclear Plant (NGNP) Project has become urgent. The System Interface and Support Systems Area under the DOE NHI is the most direct link (both organizationally and physically) to the NGNP Project, and the technical solutions provided by either project for the IHX and intermediate heat transfer loop will need to be suitable for both programs. This requires an understanding of the technical issues that are common to both programs that are related to the system interface. Revision of the Technical Issues Map was performed with this fact in mind. NHI-specific technical issues are still included, but issues related to the Intermediate Heat Exchanger (IHX) are now listed too.

The technical issues have been re-arranged into thematic areas that cross the boundaries between materials, component design, safety, and modeling. Dates have been set for their resolution to guide the future planning processes, and to show when an issue must be resolved in order stay on track with the overall NHI 10-year schedule (Figure 1). The schedule of issue resolution has also been chosen so that the work performed by the NHI will be most useful to the NGNP Project.

The time span of issues has been focused on the 5-year period spanning FY07 and FY11. This time period is critical for the success of the larger demonstrations (hydrogen pilot plants, engineering-scale demonstration) that are planned to begin construction in FY11 and later. It is assumed that the technical issues associated with larger-scale deployment will become apparent after the more basic issues have been resolved, and that those issues will be identified in detail at a later time.

The technical issues listed to be resolved in 2007 are funded or will be funded in existing FY07 work packages, and will be resolved by the end of FY07.

Looking ahead to future years, there is a significant bulge in Tables 2 and 3 for the years 2008 and 2009. With the current level of funding projected to remain at about $\$ 3 \mathrm{M}$ per year through 2010 for the Systems Interface and Support Systems area under the DOE NHI, there will not be enough funding to solve all of the issues by the time needed. The work being performed at UNLV will continue to be funded at about $\$ 2 \mathrm{M}$ per year, but there will remain only about $\$ 1 \mathrm{M}$ or less to fund projects at the national laboratories, and it is at the national laboratories where the technical integration activities will take place. Many of the issues listed to be resolved in the years 2008 and 2009 involve technical integration and engineering studies, and there will not be enough money to pay for those activities under the DOE NHI alone. Either additional funding

must come from the DOE NHI to cover the shortfall (additional millions), or substantial funding must come from the NGNP Project to cover the issues not addressed by NHI. Not funding the technical work to resolve some of the technical issues listed will not necessarily prevent the deployment of the engineering-scale NGNP in future years at the scheduled time, but will certainly increase the technical, safety and economic risks and may lead to costly repairs, higher equipment replacement rates, and degraded performance once the larger plant is operating.

The schedule of resolution provided in the tables can be met if adequate funds are provided, and there are no known technical or engineering limitations that would prevent 
resolution of the higher-level issues (i.e., use of liquid salt or helium for intermediate heat transport loop, general materials and components issues, balance-of-plant and infrastructure issues, and issues related to safety and general operations) if adequate funding is provided when needed. Certainly more detailed project schedules and cost estimates must be developed, and these will be provided in future revisions to this report. 


\section{TEXT REFERENCES}

S.R. Sherman, "FY06 Status of System Interface and Support Systems R\&D Areas", INL/EXT-06-11728, Sept. 2006.

\section{REPORT OR PROJECT REFERENCES}

$\underline{2004}$

UNLV 1Q_2004: Perret, R.F.D., "High Temperature Heat Exchanger Project: Quarterly Progress Report, October 1, 2003 through December 31, 2003”, UNLV Research Foundation, January 2004.

UNLV 2Q_2004: Perret, R.F.D., "High Temperature Heat Exchanger Project: Quarterly Progress Report, January 1, 2004 through March 31, 2004”, UNLV Research Foundation, March 2004.

UNLV 3Q 2004: Hechanova, A.E., "High Temperature Heat Exchanger Project: Quarterly Progress Report, April 1, 2004 through June 30, 2004”, UNLV Research Foundation, June 2004.

UNLV 4Q_2004: Hechanova, A.E., "High Temperature Heat Exchanger Project: Quarterly Progress Report, July 1, 2004 through September 30, 2004”, UNLV Research Foundation, October 2004.

ANL W7500-001-ES-00: Sherman, S.R., Barber, D.B., Kolts, J.H., "Reactor/Process Interface Requirements", ANL W7500-0001-ES-00, Revision 0, July 2004.

ANL W7500-002-ES-00: Sherman, S.R., Simpson, M.F., Ginosar, D., Lillo, T., Peterson, P., Ballinger, R., Roy, A., Hechanova, A., Kolts, J.H., "Reactor/Process Interface Heat Exchanger and Intermediate Loop Technical Issues", ANL W7500-0002ES-00, Revision 0, September 2004.

ANL W7500-003-ES-00: Vaden, D., Simpson, M.F., Sherman, S.R., Kolts, J.H., "Balance of Plant Requirements for a Nuclear Hydrogen Pilot Plant", ANL W7500-0003ES-00, Revision 0, September 2004.

INEEL EXT-04-01791: Anderson, R.P., Park, C.V., Ginosar, D.M., Perkowski, J.C., Carrington, R.A., Ridgway, W.D., Sherman, S.R., Anderson, M.R., Herring, J.S., Pickard, P.S., Doctor, R.D., Montgomery, R.A., Sandvig, M.D., "Infrastructure 
Requirements for a Nuclear Hydrogen Production Plant”, INEEL/EXT-04-01791, Revision 0, March 2004.

$\underline{2005}$

UNLV 1Q_2005: Hechanova, A.E., "High Temperature Heat Exchanger Project: Quarterly Progress Report, October 1, 2004 through December 31, 2004”, UNLV Research Foundation, January 2005.

UNLV 2Q 2005: Hechanova, A.E., "High Temperature Heat Exchanger Project: Quarterly Progress Report, January 1, 2005 through March 31, 2005”, UNLV Research Foundation, March 2005.

UNLV 3Q_2005: Hechanova, A.E., "High Temperature Heat Exchanger Project: Quarterly Progress Report, April 1, 2005 through June 30, 2005”, UNLV Research Foundation, April 2005.

UNLV 4Q_2005: Hechanova, A.E., "High Temperature Heat Exchanger Project: Quarterly Progress Report, July 1, 2005 through September 30, 2005”, UNLV Research Foundation, October 2005.

UNLV 2005: Hechanova, A.., "High Temperature Heat Exchanger Annual Report", UNLV Research Foundation, October 2005.

INL EXT-05-00137: Smith, C., Beck, S., Galyean, B., "An Engineering Analysis for Separation Requirements of a Hydrogen Production Plant and High-Temperature Nuclear Reactor", INL/EXT-05-00137 Rev 0, March 2005.

INL EXT-05-00453: Davis, C.B., Oh, C.H., Barner, R.B., Sherman, S.R., Wilson, D.F., "Thermal-Hydraulic Analysis of Heat Transfer Fluid Requirements and Characteristics for Coupling a Hydrogen Production Plant to a High-Temperature Nuclear Reactor", INL/EXT-05-00453, June 2005.

INL EXT-05-00690: Lillo, T.M., Williamson, R.L., Reed, T.R., Davis, C.B., Ginosar, D.M., "Engineering Analysis of Intermediate Loop and Process Heat Exchanger Requirements to Include Configuration Analysis and Materials Needs", INL/EXT-0500690, September 2005.

NERI 05-032: Nagle, D.C., Herman, C., "Silicon Carbide Ceramics for Compact Heat Exchangers", Johns Hopkins University Advanced Technology Laboratory, Project 05032, Nuclear Hydrogen Initiative.

NERI 05-154 1Q: Sridharan, K., Anderson, M. Corradini, M., "Molten Salt Heat Transport Loop: Materials Corrosion and Heat Transfer Phenomena, Quarterly Progress Report”, April 2005 to June 2005, NERI Project 05-154, University of Wisconsin, Nuclear Hydrogen Initiative. 
NERI 05-154 2Q: Sridharan, K., Anderson, M., Corradini, M., "Molten Salt Heat Transport Loop: Materials Corrosion and Heat Transfer Phenomena, Quarterly Progress Report”, July 2005 to September 2005, NERI Project 05-154, University of Wisconsin, Nuclear Hydrogen Initiative.

$\underline{2006}$

UNLV 1Q_2006: Hechanova, A.E., "High Temperature Heat Exchanger Project: Quarterly Progress Report, October 1, 2005 through December 31, 2005”, UNLV Research Foundation, January 2006.

UNLV 2Q_2006: Hechanova, A.E., "High Temperature Heat Exchanger Project: Quarterly Progress Report, January 1, 2006 through March 31, 2006”, UNLV Research Foundation, April 2006.

UNLV 3Q 2006: Hechanova, A.E., "High Temperature Heat Exchanger Project: Quarterly Progress Report, April 1, 2006 through July 31, 2006”, UNLV Research Foundation, August 2006.

UNLV 4Q_2006: Hechanova, A.E., "High Temperature Heat Exchanger Project: Quarterly Progress Report, August 1, 2006 through September 30, 2006”, UNLV Research Foundation, October 2006.

INL EXT-06-11232: Ward, B., "Balance of Plant Requirements for a Nuclear Hydrogen Plant”, INL/EXT-06-11232, April 2006.

INL EXT-06-11482: Russel, M.J., “Assessment of Codes and Standards Applicable to a Hydrogen Production Plant Coupled to a Nuclear Reactor”, INL/EXT-06-11482, June 2006.

ORNL TM-2006 69: Williams, D.F., "Assessment of Candidate Molten Salt Coolants for the NGNP/NHI Heat-Transfer Loop”, ORNL/TM-2006/69, June 2006.

INL EXT-05-00137 Rev 1: Smith, C., Beck, S., Galyean, B., “An Engineering Analysis for Separation Requirements of a Hydrogen Production Plant and High-Temperature Nuclear Reactor", INL/EXT-05-00137 Rev. 1, July 2006.

ORNL TM-2006 563: Sherman, S.R., Pawel, S.J., Wilson, D.F., "NHI Materials and Components Development Plan”, ORNL/TM-2006/563, September 2006.

NERI 05-032: Nagle, D.C., Herman, C., "Silicon Carbide Ceramics for Compact Heat Exchangers", Johns Hopkins University Advanced Technology Laboratory, Project 05032, Nuclear Hydrogen Initiative. 
NERI 05-154 3Q: Sridharan, K., Anderson, M., Corradini, M., "Molten Salt Heat Transport Loop: Materials Corrosion and Heat Transfer Phenomena, Quarterly Progress Report”, October 2005 through December 2005, NERI Project 05-154, University of Wisconsin, Nuclear Hydrogen Initiative.

NERI 05-154 Y1: Sridharan, K., Anderson, M., Allen, T., Corradini, M., "Molten Salt Heat Transport Loop: Materials Corrosion and Heat Transfer Phenomena", April 2006, NERI Project 05-154, University of Wisconsin, Nuclear Hydrogen Initiative.

NERI 06-154 5Q: Sridharan, K., Anderson, M., Corradini, M., Allen, T., "Molten Salt Heat Transport Loop: Materials Corrosion and Heat Transfer Phenomena, Quarterly Progress Report", April 2006 to June 2006, NERI Project 05-154, University of Wisconsin, Nuclear Hydrogen Initiative.

NERI 06-154 6Q: Sridharan, K., Anderson, M., Corradini, M., Allen T., Olsen, L., Ambrosek, J., "Molten Salt Heat Transport Loop: Materials Corrosion and Heat Transfer Phenomena, Quarterly Report", July 2006 to September 2006, NERI Project 05-154, Nuclear Hydrogen Initiative.

NERI 06-024: Newkirk, J., "Ni-Si Alloys for the S-I Reactor/Hydrogen Production Process Interface”, University of Missouri-Rolla, Project 06-024, Nuclear Hydrogen Initiative.

NERI 06-041: Barton, P., "Dynamic Simulation and Optimization of Nuclear Hydrogen Production Systems", Massachusetts Institute of Technology, Project 06-041, Nuclear Hydrogen Initiative.

\section{WORK PACKAGE DESCRIPTIONS}

N-AN07SS0101: Steady State and Transient Modeling of Combined Nuclear Hydrogen Plant, Argonne National Laboratory, FY07 \$180K. Work Scope: The DOE NHI is developing hydrogen production technologies to be coupled with an advanced Gen IV nuclear energy system. Argonne National Laboratory (AN) is assisting this development in part by helping to create and test integrated system models that will be used to study system configurations, optimize operating conditions, and examine transient behaviors such as experienced during start-up, shudown, and off-normal events. ANL will assist the Idaho National Laboratory (INL) in the development of steady-state and transient integrated models. ANL will also participate in an I-NERI project with the Korea Atomic Energy Research Institute (KAERI) for the development of HyPEP. HyPEP (Hydrogen Process Efficiency Program) will be a GUI-operated software package that will allow for rapid assessment of differing configurations of electrical power conversion units, intermediate loop designs, and nuclear plant and hydrogen plant operating 
conditions with the goal of determining overall hydrogen process efficiency. The scope of work to be accomplished in FY07 is the following:

1. Assess methods and models for developing dynamic simulations of the system interface and related components.

2. Perform dynamic analysies of coupled nuclear plant/hydrogen plant.

3. Work with INL and KAERI to prepare the HyPEP software for beta-testing in early 2008 .

N-ID07SS0101: UNLV NHI Materials Support, FY07 \$500K. Work Scope: This work package covers work to be performed at the University of Nevada, Las Vegas, and its sub-contractors in the area of materials in support of the DOE Nuclear Hydrogen Initiative. The focus of work in FY07 will be on two major areas: 1. Continue studies of mechanical characteristics and corrosion resistance of alloys under elevated temperatures and chemical environment.

2. Develop an approach to understand reliability of ceramics under elevated temperatures. Effect of micro-features on the strength of ceramics will also be explored.

N-ID07SS0102: UNLV NHI Momentum/Heat/Mass Transfer, FY07 \$500K. Work Scope: This work package covers work to be performed at the University of Nevada, Las Vegas, and its sub-contractors in the area of momentum/heat/mass transfer in support of the DOE Nuclear Hydrogen Initiative. The work will be managed by an associate technical director employed by UNLV and by the national Technical Director. The focus of work in FY07 will be on the analysis of specific sulfuric acid decomposer and heat exchanger concepts, the testing of prototype heat exchanger channels, thermal insulation concepts, and related activities. More precise definition of funding and work tasks will be provided at a later time after the FY07 budget is appropriated and upon agreement of work scope between the associate technical director and the national technical director.

N-ID07SS0103: UNLV NHI Liquid Salt Systems, FY07 \$500K. Work Scope: This work package covers work to be performed at the University of Nevada, Las Vegas, and its sub-contractors in the area of liquid salt systems support of the DOE Nuclear Hydrogen Initiative. The work will be managed by an associate technical director employed by UNLV and by the national Technical Director. The focus of work in FY07 will be on the analysis of practical liquid salt heat transfer systems, liquid salt chemistry and corrosion, properties determination, and related activities. More precise definition of funding and work tasks will be provided at a later time after the FY07 budget is appropriated and upon agreement of work scope between the associate technical director and the national technical director.

N-ID07SS0104: UNLV NHI Materials/Surface Characterization, FY07 \$300K. Work Scope: This work package covers work to be performed at the University of Nevada, Las Vegas, and its sub-contractors in the area of materials/surface characterization support of the DOE Nuclear Hydrogen Initiative. The work will 
be managed by an associate technical director employed by UNLV and by the national Technical Director. The focus of work in FY07 will be on the surface characterization of high temperature electrolysis electrodes, analyses related to integrated lab-scale (ILS) materials, degradation mechanisms, materials/surface analysis studies related to hydrogen production process membranes, and related activities. More precise definition of funding and work tasks will be provided at a later time after the FY07 budget is appropriated and upon agreement of work scope between the associate technical director and the national technical director.

N-ID07SS0105: UNLV NHI Chemistry Support, FY07 \$200K. Work Scope: This work package covers work to be performed at the University of Nevada, Las Vegas, and its sub-contractors in the area of chemistry support for the DOE Nuclear Hydrogen Initiative. The work will be managed by an associate technical director employed by UNLV and by the Technical Director. The focus of work in FY07 will be on tritium diffusion and isotope exchange, identification and/or development of analytical techniques for the integrated lab-scale (ILS) and pilotscale hydrogen production plants, and other chemistry-related activities. More precise definition of funding and work tasks will be provided at a later time after the FY07 budget is appropriated and upon agreement of work scope between the associate technical director and the national technical director.

N-ID07SS0106: Measurement of Mechanical Alloy Properties at UNLV - FY06 Carryover, FY06 \$532K. Work Scope: This work package covers work that was planned for execution in FY06, but due to equipment problems and problems related to funding allocation, will be performed in FY07 at UNLV. Work to be performed in this work package is funded entirely by FY06 carryover money and does not include any tasks that will be funded by FY07 money. Specific activities in this work package include: 1) Complete tensile property measurements of C22, C-276, Waspaloy, and 800H that were planned for completion in FY06, 2) Stress corrosion cracking studies of metal alloys exposed to sulfuric acid solutions, 3) Crack growth rate measurements of samples exposed to sulfuric acid solutions, 4) Crack growth rate measurements of alloys exposed to cyclic loads in an air environment, 5) Fracture toughness testing of specimens in air.

N-ID07SS0107: Corrosion and Crack Growth Studies in HIx Solutions at General Atomics - FY06 Carryover, FY06 \$135K. Work Scope: This work package covers tasks to be performed by General Atomic while working under a subcontract with UNLV. Funding for this work is provided by FY06 carryover and does not include any new FY07 money. The work activities to be performed under this work package include: 1) Continued studies of stress corrosion cracking in HIx environments, 2) Corrosion testing with weldments, c-rings, and $\mathrm{u}$-bend specimens for the purposes of studying crack initiation in HIx environments, 3) Studies of the effects of contaminants on HIx corrosion, and 4) Construction and testing of an HIx circulation loop for the testing of valves, pumps, and other components. 
N-ID07SS0108: Numerical Analysis of Advanced Heat Exchanger Concepts at UNLV FY06 Carryover, FY06 \$72K. Work Scope: In the development of new heat exchangers and high-temperature components, computational analyses are often needed to predict component function, study potential mechanical and thermal stresses, and to provide the basis for optimized component designs. UNLV will assist in the develoment of advanced heat exchanger concepts and other components by performing numerical analyses of proposed heat exchanger concepts for sulfuric acid decomposition for the S-I process. Of particular interest is the Sandia bayonet design for the S-I decomposition step. Laboratory work has begun on this concept, but little is known about its potential scaleability, stress concentrations, temperature, pressure, and reactivity profiles, and so on. UNLV will provide computational or numerical analyses of the Sandia bayonet design to the extent that the available FY06 carryover money allows. This work package only includes FY06 carryover funds and does not include any new FY07 funding. Work performed in this work package will likely be continued in another FY07 work package containing new FY07 funding.

N-ID07SS0109: C-SiC Materials for HTHX's at UC-Berkeley - FY06 Carryover, FY06 $\$ 70 \mathrm{~K}$. Work Scope: UC-Berkeley is engaged in experiments involving the development and construction of $\mathrm{C} / \mathrm{SiC}$ composite heat exchangers for hightemperature applications as part of the UNLV High Temperature Heat Exchanger Project. Due to delays in receiving FY06 funding and problems with a subcontract with COI (Composite Optics Inc.), some of the work tasks in FY06 work package ID06SS13 will need to be extended into FY07. These tasks are the following:

1) Perform helium permeation testing under hot test conditions, 2) Identification and demonstration of optimized candidate ceramic heat exchanger materials and fabrication methods, and scale size and design to demonstrate prototype-scale fabrication, 3) Perform studies of chemical and tritium safety and corrosion control methods in ceramic heat exchangers with liquid salt as heat transfer fluid.

N-ID07SS0110: Ceramic Heat Exchanger Development for Application to NHI Hydrogen Production Processes, FY06 \$32,688. Work Scope: This task is a carry-over of the work Proposed for FY06. The FY06 work has been intentionally delayed to help bridge the funding gap before the next fundung arrives. The primary work for FY05 includes three sub-tasks: 1) Materials Characterization for the SI Decomposition Process, 2) Ceramic Heat Exchanger Development for SI Decomposition, and 3) Materials Development for O2 Recovery Processes. The following describes the remaining activities:

1) SI Decomposition Materials - The initial screening of the candidate materials is complete; however the long term exposure tests to assess thermal and environmental effects will not be completed until October. Once complete, the results of these material tests must be formalized into a Materials Testing Report. 2) SI Decomposer Design - The revision 2.0 of the full-size design is scheduled to be completed and reported by Mid-November. In parallel, the validation of the 
heat transfer test rig also needs completion. Additional design activities include continued collaboration with UNLV's Numerical modeling personnel.

3) $\mathrm{O}_{2}$ Recovery Heat Exchanger - Multiple materials have been screened, although Silicon Nitride has yet to be exposed. The conceptual design of this heat exchanger has been completed and is awaiting formailization in to a report to be completed in October.

In order to continue support for the UNLV \& NHI programs, additional budget will be required for travel.

N-ID07SS0111: Ceramic Heat Exchanger Development for Application to NHI Hydrogen Production Processes, FY06 \$150K. Work Scope: This bridging funding is to continue the progress in developing ceramic-based heat exchangers for the NHI. The end objective of this development is the fabrication of full-size wafers ready for experimental evaluation. In order to attin this goal 3 sub-tasks have been defined: 1) Materials Characterization for H2SO4 Service, 2) Ceramic Heat Exchanger scale-up, and 3) Development of Catalytic Substrates. The following describes these activities:

1) Material Characterization - The candidate materials will undergo more extensive $\mathrm{H} 2 \mathrm{SO} 4$ corrosion testing at decomposition temperatures and potentially boiling temperatures/conditions. Additionally, parametric studies for processing silicon carbide will be made to reduce its thermal conductivity. This will be included into a Materials Testing Report.

2) HX Scale-up - In collaboration with UNLV, the full-size design will be advanced to revision 2.5. Based on this design full-size wafers will be constructed for evaluation testing. This sub-task also includes the development and characterization of joining (ceramic to metal and ceramic to ceramic) techniques required for demonstration of full-size components. This will be included into a Design Report.

3) Catalyst Substrates - The preliminary work in developing catalytic reactors will require development of porous substrates. This sub-task will develop methodologies for incorporating porous substrates into the decomposer design. This will be included into a Design Report.

N-ID07SS0112: UNLV RF High Temperature Heat Exchanger Project - FY06 Carryover, FY06 \$602K. Work Scope: The UNLV Research Foundation will continue the implementation of the partnership between universities, private industry and national laboratories to identify and test high temperature materials and designs for NHI heat exchangers. The work performed by this partnership will identify candidate materials, perform corrosion and physical property tests necessary for NHI heat exchangers needed for thermochemical cycles and high temperature electrolysis, and perform prototype testing. All UNLV RF projects supporting the DOE NHI are reviewed directly by the technical directors, technical integrator, and DOE personnel. This Work Package covers the UNLVRF program administration including technical development and award processing, coordination activities required to support the technical work performed by and under contract to UNLVRF, and includes the scope of work 
performed at UNLV for project management, chemistry support research, and prototypical testing. In addition, seven work packages funded by FY06 carryover funds are administered under this work package:

1. - C-SiC Materials for HTHXs at UCB (N-ID07SS0109 - UCB)

2. - Pt-added Alloy Development (WP\# TBD - MIT)

3. - Corrosion and Crack Growth Studies in HIx Solutions at General Atomics (NID07SS0107- GA)

4. - Ceramic Heat Exchanger Development for Application to NHI (WP\# TBD -

Ceramatec)

5. - High Temperature Electrolysis Experimental Development (N-ID07EL0201 UNLV)

6. - Measurement of Alloy Mechanical Properties at UNLV (N-ID07SS0106 UNLV)

7. - Numerical Analysis of Advanced Heat Exchanger Concepts at UNLV (NID07SS0108 - UNLV)

The scope of work for the following three UNLV projects are included in this work package:

1. - Administration of the UNLVRF HTHX Project including contracts, communications, collaboration and meeting coordination, and ad hoc project meetings such as the Liquid Salt Technical Working Group and the Materials Workshop hosted by UNLV (UNLV PI: Anthony Hechanova)

2. - High Temperature Heat Exchanger Prototype Testing (UNLV, PI: Samir Moujaes)

3. - Analytical Studies of Materials in the S-I cycle (UNLV, PI: Allen Johnson) In FY07, the initial UNLV Research Foundation projects (FY04-FY06) will be wrapping up and these closure activities are covered under this work package using FY06 carryover funding. New FY07 research activities coordinated by the UNLV Research Foundation funded by FY07 funds will be covered under different work packages (i.e., N-ID07SS0101, N-ID07SS0102, N-ID07SS0103, N-ID07SS0104, and N-ID07SS0105). The UNLVRF will also continue to coordinate extensive communication between members of the university consortium for materials selection and development and heat exchanger design, contract monitoring and reporting. Milestones and deliverables specific to the activities above, but not included in this WP are detailed in specific WPs and UNLV RF proposals.

High Temperature Heat Exchanger Prototype Testing: This task will complete experimental testing on the different configurations of heat exchangers such as the staggered fin arrangements. The establishment and validation of the determination of the conductivity and optical absorption coefficient for fluids that absorb radiation energy passing through them will also be completed. This concept is needed eventually if properties of molten salts such as Flinak would be used in the intermediate HX. Finally, the CFD results for hydrodynamics and thermally for the flow and heat exchanger using the staggered fin geometry experimentally will be locally validated.

Analytical Studies of HI Exposure on Structural Materials at High Temperatures: The goal of the project is to aid in the identification of suitable heat exchanger 
material candidate(s) for the HI Decomposition process within the SI Thermochemical Cycle for hydrogen production. In FY06, SEM, EDX, WDS, and XPS was used to study the structure and composition of Ta and $\mathrm{Nb}$ alloys as well as $\mathrm{SiC}$ and $\mathrm{Si} 3 \mathrm{~N} 4$ ceramics and their corrosion layers previously identified as suitable development candidates. For FY07, the study of these and other development candidates will continue. Sample preparation facilities have been constructed that can remove the last traces of HI from the test materials, making them safe for study in vacuum based analytical instruments. The instrument will be maintained and upgraded for futher work involving these materials at high temperature and corrosive environments in-situ using mass spectrometry. The samples will also be studied using other techniques (XRF, XRD,etc.) as appropriate. The results will provide data on the effect of composition and material processing on the corrosion resistant of the candidate materials.

N-ID07SS0113: The Development of Self-Catalytic Materials for Thermochemical Water Splitting Using Sulfur-Iodine Process, FY06 \$110K. Work Scope: Activities will be focused in the following areas: (1) The fabrication of several platinum-containing alloys based on the Alloy 800 and Alloy 617 chemistries. These alloys will include the following: Alloy $800+1 \mathrm{wt} \% \mathrm{Pt}$, Alloy $800+2 \mathrm{wt} \% \mathrm{Pt}$, Alloy $617+1 \mathrm{wt} \% \mathrm{Pt}$, and Alloy $617+2 \mathrm{wt} \% \mathrm{Pt}$, (2) the characterization of these alloys in the following areas: microstructurally, electrochemically, catalyst effectiveness, and mechanical properties-if sufficient material is available.

N-IN07SS0101: Steady-State and Transient Modeling of Combined Nuclear Hydrogen Plant, FY07 \$210K. Work Scope: DOE NHI is developing hydrogen production technologies to be coupled with an advanced Gen IV nuclear energy system. Idaho National Laboratory (IN) is participating in this development effort by helping to create and test integrated system models that will be used to study system configurations, optimize operating conditions, and examine steady-state operations and transient behaviors that would occur during start-up, shutdown and off-normal events. IN, with the assistance of Argonne National Laboratory (AN), will participate in an I-NERI project with the Korea Atomic Energy Research Institute (KAERI) for the development of the Hydrogen Process Efficiency Program software (HyPEP). HyPEP will be a GUI-operated software package that will allow for the rapid assessment of differing configurations of electrical power conversion units, intermediate loop designs, and nuclear plant and hydrogen plant operating conditions with the goal of determining overall hydrogen production efficiency. As a corollary assignment, IN will assist AN in the development of transient models. The scope of work to be completed in FY07 is the following: 1) Determine efficient power conversion unit (PCU) configurations for electrical generation, 2) Explore design options for the combined plant PCU, choice of working fluid, and other options, 3) Couple reference combined plant configuration with detailed HTE flowsheet and explore coupling with available S-I flowsheet(s), 4) Work with AN and KAERI to prepare the HyPEP software for beta-testing in early 2008, and 5) With AN and KAERI, 
issue annual technical report detailing the work performed during this collaboration.

N-IN07SS0102: Technical Director and Project Management Support for the DOE NHI, FY07 \$410K. Work Scope: The NHI is developing hydrogen production to be coupled with an advanced nuclear energy system being developed as part of the Generation IV Nuclear Energy Systems Initiative. The Idaho National Laboratory (INL) will support the DOE NHI in part by coordinating the overall research effort as Technical Director, providing project management support for PICS reporting, and by helping to develop and implement the DOE NHI Materials and Components Test Plan. Scope to be completed in this IN work package during FY07 is the following:

1. Support system interface and support systems (SI\&SS) activities as needed for DOE NHI as techical director.

2. Provide quarterly updates of the map of SI\&SS technical activities and corresponding research and development.

3. Produce year-end summary of SI and SS research and development that relates technical issues to ongoing work, and containing near-term research needs and directions.

4. Support I-NERI and NERI collaborations as needed.

N-OR07SS0101: Development of NHI Materials and Components Test Plan, FY07 $\$ 60 \mathrm{~K}$. Work Scope: The DOE NHI is developing hydrogen production technologies to be coupled with an advanced Gen IV nuclear energy system. Oak Ridge National Laboratory is assisting in the development of this effort by serving as editor and chief reviewer of the NHI Materials and Components Test Plan. The NHI Materials and Components Test Plan will define the decision process for determining which materials and component designs are chosen for further development and, ultimately, pilot-scale testing. The Plan will be written with the assistance of the Idaho National Laboratory and will be reviewed by the NHI leadership team at certain intervals to obtain consensus on its contents. The scope of work to be completed in FY07 is the following:

1. With INL, develop draft plan and use the S-I decomposer as an example component to illustrate the decision process.

2. With INL, issue the NHI Materials and Components Test Plan.

3. Assist in its implementation. 